\title{
The hepatic clearance of recombinant tissue-type plasminogen activator decreases after an inflammatory stimulus
}

M.R. Nagaoka1,2,

M. Kouyoumdjian ${ }^{1,2}$ and D.R. Borges ${ }^{1,3}$

\author{
${ }^{1}$ Laboratório de Hepatologia Experimental, and \\ Departamentos de ${ }^{2}$ Bioquímica and 3 M edicina, \\ Universidade Federal de São Paulo, São Paulo, SP, Brasil
}

\section{Correspondence \\ D.R. Borges \\ Laboratório de Hepatologia \\ Experimental, UNIFESP \\ Rua Jabuticabeiras, 807 \\ 05674-011 São Paulo, SP \\ Brasil \\ E-mail: drborges.dmed@epm.br}

Research supported by CNPq (No. 520281/96-9) and PRONEX (No. 41.96.0873.00). Publication supported by FAPESP.

Received June 7, 1999 Accepted November 4, 1999

\section{Abstract}

We have shown that tissue-type plasminogen activator (tPA) and plasma kallikrein share a common pathway for liver clearance and that the hepatic clearance rate of plasma kallikrein increases during the acute-phase (AP) response. We now report the clearance of tPA from the circulation and by the isolated, exsanguinated and in situ perfused rat liver during the AP response (48-h ex-turpentine treatment). For the sake of comparison, the hepatic clearance of a tissue kallikrein and thrombin was also studied. We verified that, in vivo, the clearance of ${ }^{125} \mathrm{I}$-tPA from the circulation of turpentine-treated rats $(2.2 \pm 0.2 \mathrm{ml} /$ $\min , \mathrm{N}=7)$ decreases significantly $(\mathrm{P}=0.016)$ when compared to normal rats $(3.2 \pm 0.3 \mathrm{ml} / \mathrm{min}, \mathrm{N}=6)$. The AP response does not modify the tissue distribution of administered ${ }^{125} \mathrm{I}-\mathrm{tPA}$ and the liver accounts for most of the ${ }^{125} \mathrm{I}$-tPA $(>80 \%)$ cleared from the circulation. The clearance rate of tPA by the isolated and perfused liver of turpentine-treated rats $(15.5 \pm 1.3 \mu \mathrm{g} / \mathrm{min}, \mathrm{N}=4)$ was slower $(\mathrm{P}=$ $0.003)$ than the clearance rate by the liver of normal rats $(22.5 \pm 0.7 \mu \mathrm{g} /$ $\min , \mathrm{N}=10$ ). After the inflammatory stimulus and additional Kupffer cell ablation $\left(\mathrm{GdCl}_{3}\right.$ treatment), tPA was cleared by the perfused liver at $16.2 \pm 2.4 \mu \mathrm{g} / \mathrm{min}(\mathrm{N}=5)$, suggesting that Kupffer cells have a minor influence on the hepatic tPA clearance during the AP response. In contrast, hepatic clearance rates of thrombin and pancreatic kallikrein were not altered during the AP response. These results contribute to explaining why the thrombolytic efficacy of tPA does not correlate with the dose administered.

\section{Introduction}

Activation of the blood coagulation system under physiological or pathological conditions is responsible for the formation of intravascular fibrin clots $(1,2)$. Clot dissolution is a process essential for the maintenance of blood fluidity and is achieved by the

\section{Key words}

- Liver clearance

- Inflammation

- Kallikrein

- Thrombin

- Tissue-type plasminogen activator$$
\ldots . . . . . . . .
$$ 
(4-6 min in humans), high doses of tPA are required to obtain thrombolysis (3). The liver is the major site for tPA clearance from the circulation and the two most important hepatic receptors for tPA clearance are the low-density-lipoprotein-receptor-related protein (LRP) on parenchymal cells and the mannose receptor on liver endothelial and Kupffer cells. Other receptors marginally contribute to tPA clearance (4).

The liver response to injury occupies a central position in the acute-phase (AP) response. The hepatic modulation of the kallikrein-kinin system is altered during the AP response to inflammation, with an increase in hepatic synthesis of total kininogen (5), Tkininogen (6) and prokallikrein (7). The kallikrein-kinin system is important in the pathogenesis of the inflammatory reaction (8) and is linked to the fibrinolytic system since bradykinin is a potent stimulus of tPA secretion (9).

It has been shown that plasma levels of tPA and the complex formed by tPA with plasminogen-activator inhibitor type 1 (PAI1) are increased in patients with various liver diseases (10), perhaps because of impaired tPA clearance. During the AP response the clearance rate of plasma-kallikrein by the perfused rat liver increases (11); in contrast, the liver uptake of an asialoglycoprotein decreases during the AP response (12), suggesting that the mechanism of endocytosis mediated by different lectins is distinctly modified during the AP response. We have shown that tPA and plasma kallikrein share a common pathway for liver clearance (13). We now report the clearance of tPA from the circulation (in vivo) and by the isolated, exsanguinated and perfused rat liver during the AP response. For the sake of comparison, we also studied the hepatic clearance of porcine pancreatic kallikrein (PoPK), which is cleared through the mannose receptor (14), and thrombin (TH), which binds to liver cells but is minimally internalized (15).

\section{Material and Methods}

\section{Chemicals}

Recombinant human IPA (Actilyse ${ }^{\circledR}$ ) provided by Boehringer Ingelheim (Mannheim, Germany) was used for liver perfusion experiments; melanoma tPA from Calbiochem (San Diego, CA, USA) was iodinated and used for in vivo experiments. $\mathrm{Na}^{125} \mathrm{I}$ was obtained from Amersham (Buckingham, UK). Rat plasma thrombin and porcine pancreatic kallikrein were purchased from Sigma Chemical Co. (St. Louis, MO, USA). Acetylphenylalanine-arginine-pnitroanilide (AcPhe-Arg-pNA) was synthesized by L. Juliano (Department of Biophysics, UNIFESP, SP, Brazil). The amidolytic substrates S2238 (HD-Phe-Pip-Arg-pNA) for thrombin and S2288 (H-D-Ile-Pro-Arg-pNA) for tPA were purchased from Chromogenix (Mölndal, Sweden).

\section{Rats}

Adult male Wistar rats weighing 150$265 \mathrm{~g}$ were used according to the International Guiding Principles for Biomedical Research Involving Animals (16).

\section{Inflammatory stimulus}

To study the influence of the AP response on the hepatic clearance of tPA, TH and PoPK, rats received $0.5 \mathrm{ml}$ turpentine oil subcutaneously at each of two sites on either side of the abdomen $48 \mathrm{~h}$ before the experiment. The AP response was confirmed by the detection of serum $\alpha_{2}$ macroglobulin $\left(\alpha_{2} \mathrm{M}\right)$ by radial immunodiffusion (5). The specific antibody was donated by A.H. Gordon, National Institute for Medical Research, London.

To determine the participation of Kupffer cells in the clearance of tPA by the liver of turpentine-treated rats, $\mathrm{GdCl}_{3}$ dissolved in $0.15 \mathrm{M} \mathrm{NaCl}$ was injected through the tail 
vein at the dose of $10 \mathrm{mg} / \mathrm{kg}$ (17) $12 \mathrm{~h}$ after turpentine oil injection. The experiments were conducted $36 \mathrm{~h}$ after $\mathrm{GdCl}_{3}$ injection.

\section{tPA labeling}

tPA $(100 \mu \mathrm{g})$ in $0.05 \mathrm{M}$ sodium phosphate, $\mathrm{pH} 7.4$, was iodinated with ${ }^{125} \mathrm{I}$ (1 $\mathrm{mCi}$ ) using the chloramine $\mathrm{T}$ method (18). Unincorporated iodine was removed by gel filtration on a PD-10 column and eluted with $50 \mathrm{mM}$ sodium phosphate, $\mathrm{pH}$ 7.4. The amidolytic activity upon $\mathrm{S} 2288$ and radioactivity of the aliquots were determined. A preparation of ${ }^{125}$ I-tPA with a specific radioactivity of $2.5 \times 10^{6} \mathrm{cpm} / \mu \mathrm{g}$ protein was used.

\section{Amidolytic activity}

The amidolytic activity of tPA, TH or PoPK was assayed by incubating perfusate aliquots $(0.1 \mathrm{ml})$ at $37^{\circ} \mathrm{C}$ in a final volume $(0.2 \mathrm{ml})$ of $50 \mathrm{mM}$ Tris- $\mathrm{HCl}, 12 \mathrm{mM} \mathrm{NaCl}$, $\mathrm{pH}$ 8.0, for tPA, $15 \mathrm{mM}$ Tris- $\mathrm{HCl}, 20 \mathrm{mM}$ EDTA, pH 7.4, for $\mathrm{TH}$, and $50 \mathrm{mM}$ Tris$\mathrm{HCl}, 1 \mathrm{mM}$ EDTA, $\mathrm{pH}$ 9.0, for PoPK, at a final concentration of $0.5 \mathrm{mM}$ S2288, 0.5 mM S2238 and $0.6 \mathrm{mM} \mathrm{Ac-Phe-Arg-pNA,}$ respectively (19). The reaction was stopped with $0.8 \mathrm{ml}$ of $15 \%$ acetic acid and the absorbance of $\mathrm{p}$-nitroaniline was measured at $405 \mathrm{~nm}$. Duplicate assays were conducted and values varied less than $5 \%$.

\section{Clearance of tPA from the circulation}

Clearance of ${ }^{125}$ I-tPA from the circulation was determined in rats anesthetized with urethane $(1.3 \mathrm{mg} / \mathrm{g})$. Tracheotomy was performed and catheters were positioned into the left jugular vein and right carotid artery. ${ }^{125} \mathrm{I}$-tPA $\left(2 \times 10^{6} \mathrm{cpm}, 0.7 \mu \mathrm{g}\right)$ plus $500 \mu \mathrm{g}$ of unlabeled tPA was injected intravenously in bolus and flushed with $0.5 \mathrm{ml}$ of $0.15 \mathrm{M}$ $\mathrm{NaCl}$ solution. Blood samples were collected at 2, 5, 10, 20,30, 40, 50 and $60 \mathrm{~min}$ after administration of ${ }^{125}$ I-tPA from the carotid artery catheter into polyethylene tubes containing $0.4 \%$ sodium citrate. The aliquots were centrifuged at $5000 \mathrm{~g}$ for $10 \mathrm{~min}$, and the plasma samples $(150 \mu \mathrm{l})$ separated and precipitated with $10 \%$ trichloroacetic acid. The radioactivity of the acid precipitable protein was determined with a $\gamma$-radiation counter.

To analyze the tissue distribution of ${ }^{125} \mathrm{I}-$ tPA, 60 min after its administration the abdomen and thorax were opened and liver, heart, lung, kidney and spleen were removed and weighed and their radioactivity was measured.

\section{Liver perfusion in situ}

The livers were perfused at $37^{\circ} \mathrm{C}$ as described (20). Rats were anesthetized with urethane $(1.3 \mathrm{mg} / \mathrm{g})$ and kept alive by artificial respiration. The livers were perfused through the portal vein (inflow cannula) and thoracic inferior vena cava (outflow cannula) in an open circuit with $200 \mathrm{ml}$ of Krebs-Henseleit bicarbonate solution, $\mathrm{pH}$ 7.4. The circuit was then closed and the livers were perfused with $30 \mathrm{ml}$ of recirculating Krebs' solution containing $1 \mathrm{mg} / \mathrm{ml}$ bovine serum albumin (BSA) for $10 \mathrm{~min}$, at a constant flow of $28 \mathrm{ml} / \mathrm{min}$. The recirculating Krebs'solution was exchanged with the same volume of Krebs/BSA and a new equilibration period of $10 \mathrm{~min}$ was allowed to elapse. The peristaltic pump was then turned off and $500 \mu \mathrm{g}$ tPA, $50 \mu \mathrm{g}$ TH or $160 \mu \mathrm{g}$ PoPK was added. After 1 min of mixing and collection of aliquot " 0 ", the peristaltic pump was turned on and the perfusion reinitiated. Aliquots (1 $\mathrm{ml}$ ) of the perfusate were collected at $0,5,10$ and $20 \mathrm{~min}$ for tPA, $0,1,3,5$ and $10 \mathrm{~min}$ for $\mathrm{TH}$, and $0,10,20$ and $30 \mathrm{~min}$ for PoPK experiments.

The percentage (aliquot " 0 " taken as $100 \%$ ) of the residual amidolytic activity in the perfusate aliquots was used to calculate the half-life of disappearance $\left(\mathrm{t}^{1} / 2\right)$ and the 
clearance rate of the proteases (with the aid of the GraphPAD Prism ${ }^{\mathrm{TM}}$ software, version 1.03). The results are reported as mean \pm SEM and significant differences were determined using the Primer computer software version 3.02 (McGraw-Hill, Inc., New York, NY, USA).

To exclude possible interference with the amidolytic activities of tPA, TH or PoPK by substances liberated from the perfused liver into the perfusion medium, we incubated the perfusion medium obtained after $30 \mathrm{~min}$ of perfusion (without any protease added) with the enzymes.

In anhepatic experiments, i.e., a system without liver but with the other perfusion procedures maintained, tPA, TH or PoPK were recirculated for 15-30 $\mathrm{min}$ and the amidolytic activities assayed.

\section{Results}

\section{Control experiments}

The in vitro assays showed that the liver perfusate neither inhibited nor increased the activity of the enzymes studied (tPA, TH or PoPK). In anhepatic experiments we observed that $\mathrm{PAA}, \mathrm{TH}$ or PoPK were not inactivated after 15-30 min of recirculation.

The AP response was confirmed by the detection of $\alpha_{2} \mathrm{M}$ in the serum of turpentineand/or $\mathrm{GdCl}_{3}$-treated rats; $\alpha_{2} \mathrm{M}$ was not detected in the serum of normal rats.

To determine that Kupffer cells were ablated by the $\mathrm{GdCl}_{3}$ treatment, at the end of the perfusion experiments the livers were

Figure 1 - Organ distribution of 125I-tPA 60 min after administration to normal and turpentinetreated rats.

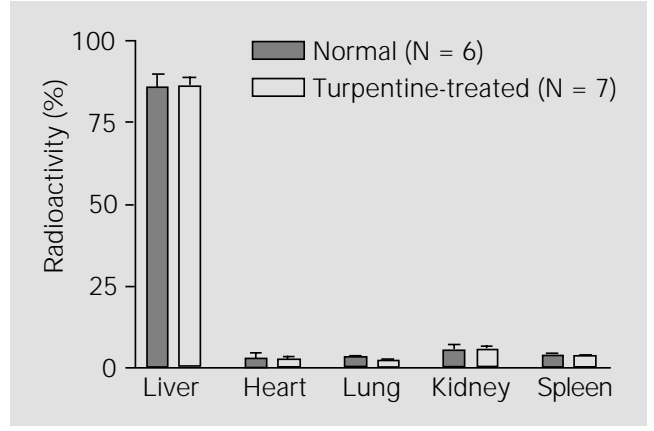

perfused with China ink (21); histological examination showed that Kupffer cells from normal rats but not those from $\mathrm{GdCl}_{3}$-treated rats were blackish.

To assure that the labeling process did not impair tPA clearance by the liver, we perfused the organ with ${ }^{125}$ I-tPA $\left(2 \times 10^{6}\right.$ cpm) plus unlabeled tPA $(500 \mu \mathrm{g})$ and verified that ${ }^{125} \mathrm{I}$-tPA was cleared $(27.4 \pm 5.2 \mu \mathrm{g}$ / min, $\mathrm{N}=5$ ) by the isolated, exsanguinated and perfused rat liver at the same rate $(\mathrm{P}=$ $0.422)$ as unlabeled tPA $(27.4 \pm 5.2 \mu \mathrm{g} / \mathrm{min}$, $\mathrm{N}=5$ ).

\section{tPA clearance from the circulation}

The clearance rates and half-lives of ${ }^{125} \mathrm{I}$ tPA were calculated from the plasma elimination curves for in bolus injection of the activator in normal or turpentine-treated rats. The plasma elimination rate of IPA in turpentine-treated rats $(2.2 \pm 0.2 \mathrm{ml} / \mathrm{min}, \mathrm{N}=7)$ decreased significantly $(\mathrm{P}=0.016)$ compared to normal rats $(3.2 \pm 0.3 \mathrm{ml} / \mathrm{min}, \mathrm{N}=$ 6). The tissue distribution of ${ }^{125} \mathrm{I}$-tPA is shown in Figure 1. It can be seen that the AP response did not modify the tissue distribution of the activator and that the liver was the major site for the efficient removal of ${ }^{125} \mathrm{I}$ tPA from the circulation in both normal and turpentine-treated rats.

\section{Hepatic clearance}

Table 1 shows that the inflammatory stimulus also influenced the clearance of tPA by the isolated liver. The clearance rate of tPA by the perfused liver from injured rats (i.e., treated with turpentine or turpentine$\mathrm{GdCl}_{3}$ ) was slower than observed in normal animals.

On the other hand, the inflammatory stimulus had no effect on the clearance rate of PoPK or TH by the perfused rat liver. The clearance rate of PoPK $(160 \mu \mathrm{g})$ (Figure 2A) by the perfused liver of normal rats $(2.4 \pm 0.1$ $\mu \mathrm{g} / \mathrm{min}, \mathrm{N}=3)$ was similar $(\mathrm{P}=0.830)$ to that 
of turpentine-treated rats $(2.3 \pm 0.3 \mu \mathrm{g} / \mathrm{min}$, $\mathrm{N}=3)$. Thrombin $(50 \mu \mathrm{g})$ was efficiently removed from the circulation by the liver (Figure 2B) of both normal $(34.8 \pm 2.9 \mu \mathrm{g} /$ $\mathrm{min})$ and turpentine-treated rats $(39.1 \pm 2.5$ $\mu \mathrm{g} / \mathrm{min})(\mathrm{P}=0.321)$.

\section{Discussion}

Receptor-mediated endocytosis is a mechanism that transports macromolecules into the cell following a series of intracellular transfers through distinct environments. This process is important for the regulation of the plasma concentration of many glycoproteins, and several types of lectins are involved in the initial step (binding) of the internalization process, which can be modified by pathological situations (22).

When complexed with an inhibitor, thrombin is cleared from the circulation by hepatocytes via receptor-mediated endocytosis; on the contrary, free TH binds to parenchymal cells but is minimally internalized (15). We now report that the uptake of free $\mathrm{TH}$ by the liver of turpentine-treated rats is not altered, suggesting that the AP response does not modify the binding of $\mathrm{TH}$ to hepatic cells. The hepatic endocytosis of pancreatic kallikrein is mediated by a specific mannose receptor (14) found mainly in liver endothelial and Kupffer cells. In this study we show that the PoPK clearance by the liver of turpentine-treated rats is not altered.

It is known that after intravenous infusion of tPA three molecular forms may be found in plasma: two active forms (free tPA and the $\mathrm{PA}-\alpha_{2} \mathrm{M}$ complex) and an inactive form (tPA-plasminogen activator inhibitor 1 (PAI-1) complex) (23). Our results showed that tPA clearance from plasma decreases in turpentine-treated rats and that the AP response does not modify the in vivo tissue distribution of ${ }^{125}$ I-tPA, with the liver being responsible for most of the ${ }^{125} \mathrm{I}$-tPA cleared from the circulation even after an inflamma- tory stimulus. We assured that labeling of tPA with ${ }^{125}$ I does not impair its clearance by the liver, a phenomenon described for plasma kallikrein (18).

In normal rats, human tPA and rat plasma kallikrein share some characteristics in their clearance by the liver and a molar excess of tPA inhibits the hepatic clearance of rat plasma kallikrein (13), suggesting a common pathway inside the organ. After an in-

Table 1 - Clearance of tPA by the isolated and exsanguinated liver of normal, turpentine- and/or $\mathrm{GdCl}_{3}$-treated rats.

ANOVA, $\mathrm{P}=0.003$; Bonferroni t-test: $\mathrm{a}>\mathrm{b} ; \mathrm{a}>\mathrm{d} ; \mathrm{a}=\mathrm{c} ; \mathrm{b}=\mathrm{c} ; \mathrm{b}=\mathrm{d} ; \mathrm{c}=\mathrm{d}$.

\begin{tabular}{lcccc}
\hline & None $^{\mathrm{a}}$ & Turpentine $^{\mathrm{b}}$ & $\mathrm{GdCl}_{3} \mathrm{c}$ & $\begin{array}{c}\text { Turpentine } \\
\text { and } \mathrm{GdCl}_{3}{ }^{\mathrm{d}}\end{array}$ \\
\hline $\begin{array}{l}\text { AP response } \\
\left(\text { serum } \alpha_{2} \mathrm{M}\right)\end{array}$ & - & ++ & + & ++ \\
$\mathrm{N}$ & 10 & 4 & 4 & 5 \\
Clearance $(\mu \mathrm{g} / \mathrm{min})$ & $22.5 \pm 0.7$ & $15.5 \pm 1.3$ & $17.5 \pm 1.4$ & $16.2 \pm 2.4$
\end{tabular}

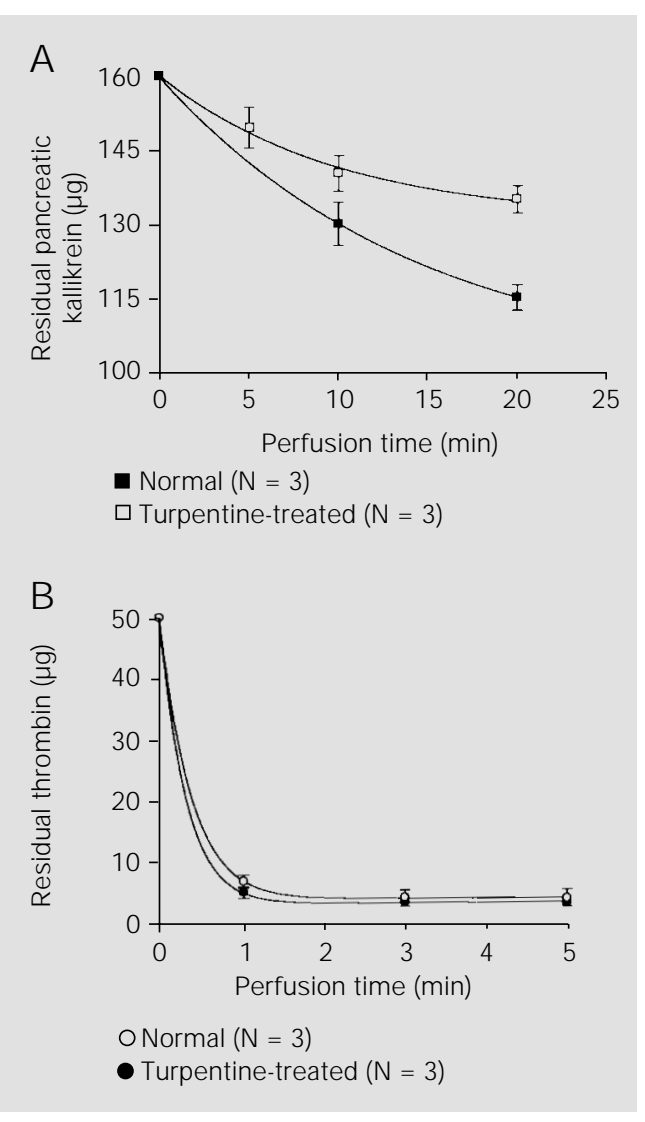

Figure 2 - Clearance of pancreatic kallikrein (A) and thrombin (B) by the isolated and exsanguinated liver of normal or turpentinetreated rats. 
flammatory stimulus the hepatic clearance rate of rat plasma kallikrein increased (11), in contrast to the tPA behavior now described. Different behavior during endocytosis of proteins that share a common plasma membrane receptor has already been described: epidermal growth factor and transforming growth factor- $\alpha$ compete for the same receptor with different affinities, which could be a consequence of differences in the mechanisms of intracellular processing (24).

The results reported here suggest that receptor-mediated endocytosis is not uniformly affected by an AP situation. After an inflammatory stimulus, proteins such as interleukin- 6 and transforming growth factor$B$ synthesized by activated Kupffer cells elicit the AP response in hepatocytes and stellate cells (25). The clearance rate of tPA by the liver of turpentine-treated rats was minimally influenced by Kupffer cells since after their ablation by $\mathrm{GdCl}_{3}$ treatment the clear- ance rate did not change, in agreement with the in vivo experiments reported by Narita et al. (4).

In the present liver perfusion experiments, we used an amount of tPA comparable to the dose therapeutically administered to humans (26). Only when the in vivo administered tPA overcomes the inhibition by PAI-1 in plasma will the (free) enzyme be therapeutically active. It is also known that the thrombolytic efficacy of tPA is not correlated with the dose administered (26). The result reported here showing that free tPA clearance by the liver is compromised during an AP situation contributes to the understanding of this fact.

\section{Acknowledgments}

We thank Miss Hercilia M. Molina for technical assistance.

\section{References}

1. Roberts HR, Monroe DM, Oliver JA, Chang J $-Y \&$ Hoffman M (1998). Newer concepts of blood coagulation. Haemophilia, 4: 331-334.

2. Levi M \& Ten Cate H (1999). Disseminated intravascular coagulation. New England J ournal of Medicine, 341: 586-592.

3. Otter M, Kuiper J , Bos R, Rijken DC \& van Berkel ThJ C (1992). Characterization of the interaction both in vitro and in vivo of tissue-type plasminogen activator (t-PA) with rat liver cells. Effects of monoclonal antibodies to t-PA. Biochemical J ournal, 284: 545-550.

4. Narita M, Bu G, Herz J \& Schwartz AL (1995). Two receptor systems are involved in the plasma clearance of tissuetype plasminogen activator (t-PA) in vivo. J ournal of Clinical Investigation, 96: 11641168.

5. Borges DR \& Gordon AH (1976). Kininogen and kininogenase synthesis by the liver of normal and injured rats. J ournal of Pharmacy and Pharmacology, 28: 44-48.

6. Barlas A, Okamoto $\mathrm{H} \&$ Greenbaum LM (1985). T-kininogen - the major plasma kininogen in rat adjuvant arthritis. Biochemical and Biophysical Research Com- munications, 129: 280-286.

7. Limãos EA, Borges DR, Souza-Pinto J C, Gordon AH \& Prado J L (1981). Acute turpentine inflammation and kinin release in rat-paw thermic oedema. British J ournal of Experimental Pathology, 62: 591-594.

8. Colman RW \& Schmaier AH (1997). Contact system: a vascular biology modulator with anticoagulant, profibrinolytic, antiadhesive, and proinflammatory attributes. Blood, 90: 3819-3843.

9. Brown NJ, Nadeau JH \& Vaughan DE (1997). Selective stimulation of tissuetype plasminogen activator (t-PA) in vivo by infusion of bradykinin. Thrombosis and Haemostasis, 77: 522-525.

10. Leiper K, Croll A, Booth NA, Moore NR, Sinclair T \& Bennett B (1994). Tissue plasminogen activator, plasminogen activator inhibitors, and activator-inhibitor complex in liver disease. J ournal of Clinical Pathology, 47: 214-217.

11. Martins $B$, Kouyoumdjian $M$, Limãos EA $\&$ Borges DR (1992). The clearance rate of plasma kallikrein by the liver increases during acute-phase response to inflammation. Agents and Actions, 37: 111-113.

12. Wong MWC \& J amieson J C (1979). Evi- dence for reduced uptake of asialo-alpha 1-acid glycoprotein during the acutephase response to inflammation. Life Sciences, 25: 827-834.

13. Nagaoka $M R$, Kouyoumdjian $M \&$ Borges DR (1996). Plasma kallikrein and tissuetype plasminogen activator compete for a common pathway into the liver. Immunopharmacology, 32: 88-90.

14. Kouyoumdjian M, Borges DR, Prado ES \& Prado J L (1989). Identification of receptors in the liver that mediate endocytosis of circulating tissue kallikreins. Biochimica et Biophysica Acta, 980: 299-304.

15. Weyer B, Petersen TE \& Sonne O (1988). Characterization of the binding of bovine thrombin to isolated rat hepatocytes. Thrombosis and Haemostasis, 60: 419427.

16. International Guiding Principles for Biomedical Research Involving Animals by the Council for International Organizations of Medical Sciences (CIOMS) (1985). Geneva, Switzerland, 1-28.

17. Sarphie TG, D'Souza NB \& Deaciuc IV (1996). Kupffer cell inactivation prevents lipopolysaccharide-induced structural changes in the rat liver sinusoid: an elec- 
tron-microscopic study. Hepatology, 23: 788-796.

18. Borges DR \& Kouyoumdjian M (1992). Chloramine $T$ impairs the receptor-mediated endocytosis of plasma kallikrein by the liver. Agents and Actions, 38 (Suppl II): $278-284$.

19. Lottenberg R, Christensen U, J ackson CM \& Coleman PL (1981). Assay of coagulation proteases using peptide chromogenic and fluorogenic substrates. Methods in Enzymology, 80: 341-361.

20. Borges DR, Gordon AH, Guimarães J A \& Prado J L (1985). Rat plasma kallikrein clearance by perfused rat liver. Brazilian J ournal of Medical and Biological Re- search, 18: 187-194.

21. Nagaoka MR, Kouyoumdjian M \& Borges DR (1997). Cava vein perfusion in situ: a tool for uptake studies. J oumal of Pharmacological and Toxicological Methods, 37: 23-26.

22. Borges DR \& Kouyoumdjian M (1994). Plasma kallikrein clearance by the liver: a review. Brazilian J ournal of Medical and Biological Research, 27: 2033-2041.

23. leko M, Sawada K, Yasukouchi T, Sakurama S, Tohma Y, Shiroshita K, Kurosawa S, Ohmoto A, Kohno M, Satoh M \& Koike T (1997). Protection by $\alpha 2-$ macroglobulin of tissue plasminogen activator against inhibition by plasminogen activator inhibitor-1. British J ournal of Haematology, 97: 214-218.

24. Ebner R \& Derynck R (1991). Epidermal growth factor and transforming growth factor- $\alpha$ : Differential intracellular routing and processing of ligand-receptor complexes. Cell Regulation, 2: 599-612.

25. Olaso E \& Friedman SL (1998). Molecular regulation of hepatic fibrogenesis. J ournal of Hepatology, 29: 836-847.

26. The National Institute of Neurological Disorders and Stroke. r-t-PA Stroke Study Group (1995). Tissue plasminogen activator for acute ischemic stroke. New England J ournal of Medicine, 333: 1581-1587. 